Article

\title{
Composite Soil Made of Rubber Fibers from Waste Tires, Blended Sugar Cane Molasses, and Kaolin Clay
}

\author{
Juan E. Jiménez ${ }^{1}$, Carlos Mauricio Fontes Vieira ${ }^{2}$ and Henry A. Colorado ${ }^{1, *}$ \\ 1 Composites Laboratory, Universidad de Antioquia UdeA, Medellín 050010, Colombia; \\ juan.jimenezh@udea.edu.co \\ 2 Materials Engineering, Faculty of Engineering, Universidade Estadual do Norte Fluminense, \\ Rio de Janeiro 28013-602, Brazil; vieira@uenf.br \\ * Correspondence: henry.colorado@udea.edu.co
}

Citation: Jiménez, J.E.; Fontes Vieira, C.M.; Colorado, H.A. Composite Soil Made of Rubber Fibers from Waste

Tires, Blended Sugar Cane Molasses, and Kaolin Clay. Sustainability 2022, 14, 2239. https://doi.org/10.3390/ su14042239

Academic Editor: Syed Minhaj Saleem Kazmi

Received: 18 January 2022

Accepted: 11 February 2022

Published: 16 February 2022

Publisher's Note: MDPI stays neutral with regard to jurisdictional claims in published maps and institutional affiliations.

Copyright: (C) 2022 by the authors. Licensee MDPI, Basel, Switzerland. This article is an open access article distributed under the terms and conditions of the Creative Commons Attribution (CC BY) license (https:// creativecommons.org/licenses/by/ $4.0 /)$.

\begin{abstract}
The use of different chemical and biological admixtures to improve the ground conditions has been a common practice in geotechnical engineering for decades. The use of waste material in these mixtures has received increasing attention in the recent years. This investigation evaluates the effects of using recycled tire polymer fibers (RTPF) and sugar molasses mixed with kaolin clay on the engineering properties of the soil. RTPF were obtained from a tire recycling company, while the molasses were extracted from a sugar cane manufacturer, both located in Colombia. RTPF is a waste and therefore its utilization is the first positive impact of this research, a green solution for this byproduct. Treated kaolin clay is widely used in many industrial processes, such as concrete, paper, paint, and traditional ceramics. The characterization was conducted with scanning electron microscopy, compression strength, particle-size distribution, $x$-ray diffraction, compressive and density tests. The results showed that the unconfined compressive strength improved from about $1.42 \mathrm{MPa}$ for unstabilized samples, to $2.04 \mathrm{MPa}$ for samples with $0.1 \mathrm{wt} \%$ of fibers, and $2.0 \mathrm{wt} \%$ molasses with respect to the dry weight of the soil. Furthermore, it was observed that soil microorganisms developed in some of the samples due to the organic nature of the molasses.
\end{abstract}

Keywords: waste tires; molasses; soil improving

\section{Introduction}

The accumulation of end-of-life tires has become a worldwide problem with dramatic consequences for sustainability and with a trend to worsen due to the increasing demand of cars, with 1.4 billion tires produced annually across the world, which is equivalent to an amount of 17,000,000 tons/year of tires used [1]. In 2017 in the United States, 287.3 million tires were disposed of, corresponding to 4.7 million tons [2]. In Colombia, an estimated 61,000 tons of tires are annually disposed of [3], from which 18,861 tons are regenerated yearly in the capital city, Bogota [4]. In this city, 15,880 tons of tires were processed and reutilized between 2016 and 2018 [5].

Due to the high stresses in car tires under normal conditions, they are fabricated from rubber matrix reinforced by textile fibers and steel wires. Combining textile fibers and steel wires make tires resistant to biodegradation and give them high strength properties [6]. All these materials can be used after the tire's life cycle. Sienkiewicz et al. [1] summarized five procedures to handle discarded tires: pyrolysis, retreading, product recycling, energy recovery, and material recycling. Retreading deals with the substitution of used parts with new ones [7], although there are serious safety concerns for the vehicle when this is used [8]. Energy process is one of the most common applications for utilizing the used tires as energy source [1]: with a calorific capacity value of $32 \mathrm{MJ} / \mathrm{kg}$, used tires compete with fuel [9]. Pyrolysis is a chemical process that gives flammable gas as byproduct of the tire waste transformation, in addition to carbon black (CBp), liquid fuel, pyrolytic oil, and pyrolysis char [10]. Product recycling involves using the discarded tires in different components, 
where recycling aims to obtain the original raw materials via processing [1]. Most of these strategies are not massively implemented in many countries representing a significant part of the world, mostly because of the costs involved in the process and other factors including absence of clear environmental laws [11].

In construction materials, perhaps the most known use for waste tires is its use in asphalt pavements to improve the concrete performance [11], although, waste tires are used in multiple applications. One of them is in low-scale retaining structures and architectural furnishing elements $[12,13]$. Two byproducts of discarded tires have been evaluated in concretes in order to know the mechanical properties: recycled tire polymer fibers (RTPF) and recycled rubber [14-16]. Moreover, steel fibers were evaluated as a potential reinforcement for concrete $[17,18]$. In another approach, the recycled tire rubber particles were combined with soil containing clay and sand as a potential new material [19-21]. Other composite materials used in construction have been studied and insulation properties were identified [22].

On the other hand, molasses are an organic byproduct of the repeated crystallization of sugar. It is a viscous syrup, with a dark brown color. The main elements in molasses are carbon and oxygen, while others in minor contents are calcium, sulfur, magnesium, chlorine, and potassium. Molasses are commonly used in the agricultural sector to control parasites [23], improve pastures [24], and to create nutritional supplements for cattle [25]. Molasses have also been used in different areas such as an additive for cement and concrete [26], during the cement production [27], stabilizer for expansive clays [28], and as a carbon source for bioremediation of contaminated soils [29].

Kaolin is a white fine-grained clay soil with kaolinite as its main constituent as hydrous aluminum silicate, composed of alumina and silica alternately stacked [30]. Kaolin has commonly been used in specific applications in paper, ceramics, refractories, plastics, rubber, adhesives, and paint industries [30]. Recently, kaolin has been used in additive manufacturing as well [31,32]. Furthermore, it was extensively used as construction material, and in its calcinated form, it has been used in concrete, for improving properties such as strength and durability [33]. Kaolin is also a very important source of alternative cements, geopolymers [34].

Several authors have addressed the use of waste materials from different origins to improve the ground, obtaining considerable improvement in the engineering properties of soils. Plastic wastes have been used to counteract traction stresses in the soil mass [35]. Ground plastic bottles have been used as reinforcement material when mixed with different soil types [36], waste fique natural fibers [37], and ashes from different processes were mixed with soils in order to develop cementing chemical reactions [38].

The present research studied an environmentally friendly alternative to the disposal of RTPF with the addition of molasses. Molasses were used as cementing material and as a matrix for the dispersion of the fibers. Characterization via X-ray diffraction (XRD), scanning electron microscopy (SEM), and shear strength, was used to evaluate the ground improvement. Finally, microorganisms that grew in the soil samples are shown.

\section{Materials and Methods}

The RTPF were obtained from a tire recycling company located at Rionegro, Colombia. Steel, rubber, and nylon wastes were mechanically separated. The nylon fiber has an average diameter of $22.4 \mu \mathrm{m}$. The residual rubber has an average size of $46 \mu \mathrm{m}$ and a concentration of $60 \mathrm{wt} \%$ with respect to the rubber weight content. Molasses were obtained from a sugar cane company, located at Colombia. Table 1 summarizes the chemical composition of molasses. Kaolin soil in natural condition was supplied by Sumicol S.A.

Figure 1a shows polymer fibers on macro-scale image, where fibers look like cotton pads with fine residual rubber particles from the recycling process. Figure $1 \mathrm{~b}$ shows a higher magnification of these fibers, revealing they are connected to one another due to the recycling process, which destroys the polymer textile and forms polymer fibers. Figure $1 \mathrm{c}$ shows the consistency of molasses. Figure $1 \mathrm{~d}$ shows the supplied raw soil. 
Table 1. SEM-EDS chemical composition for molasses.

\begin{tabular}{ccccccccc}
\hline Element & $\mathbf{O}$ & $\mathbf{C}$ & $\mathbf{K}$ & $\mathbf{C l}$ & $\mathbf{C a}$ & $\mathbf{M g}$ & $\mathbf{S}$ & Total \\
\hline Weight (\%) & 41.23 & 46.67 & 6.86 & 2.08 & 2.1 & 0.64 & 0.41 & 99.99 \\
Atomic (\%) & 51.42 & 43.7 & 2.63 & 0.88 & 0.78 & 0.39 & 0.19 & 99.99 \\
\hline
\end{tabular}
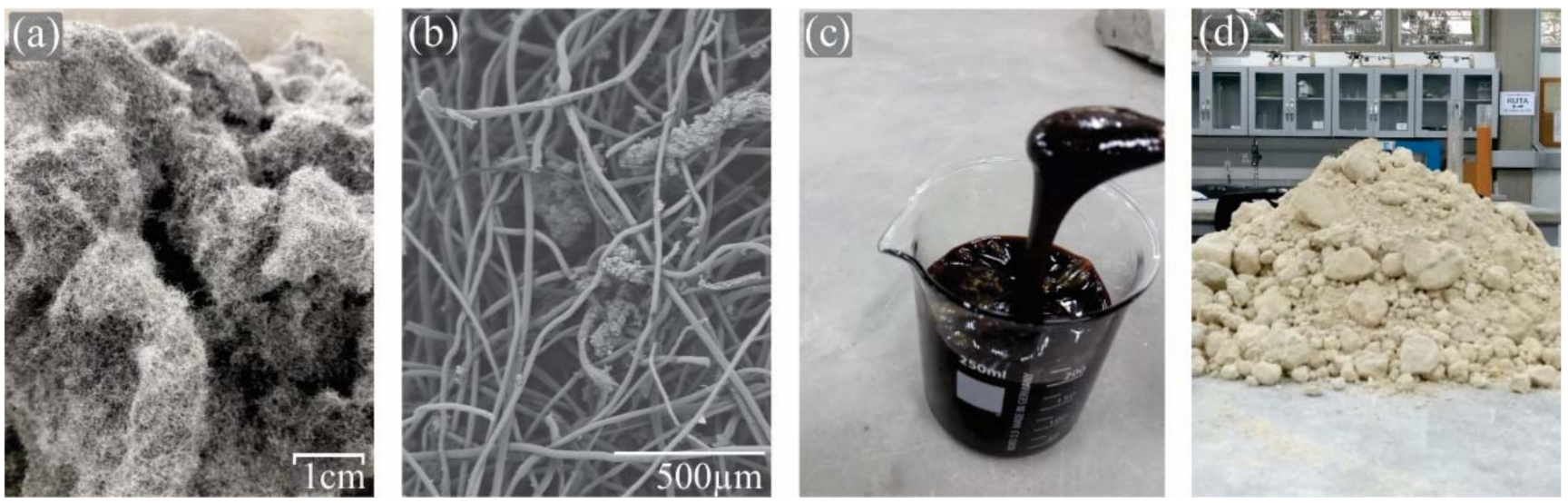

Figure 1. Materials used in this research, (a) polymer fibers, (b) magnification on polymer fibers, (c) molasses, (d) soil used in this research.

Figure 2 shows the optimum moisture (water) content showing the optimum moisture content, where soil contains 32\% of water and compacted according to ASTM D1557-12e1 achieving 1.42 MPa as its highest dry density.

\section{Optimum moisture content}

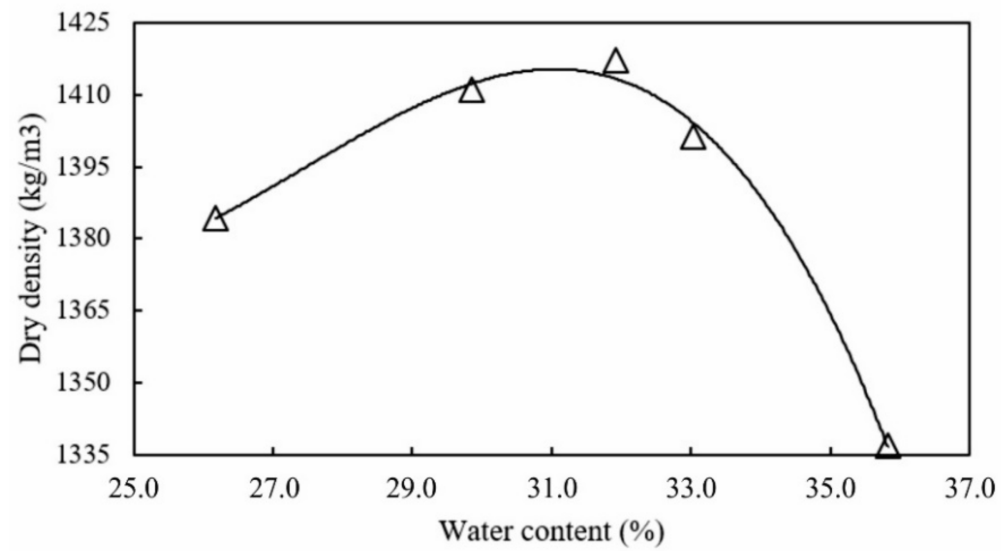

Figure 2. Optimum moisture content.

The dry kaolin clay was crushed using a hand roller in order to decrease agglomeration and have better particle size distribution. Molasses, RTPF, and water were measured by dry soil weight. Molasses and the fiber were hand mixed for three minutes until a homogenous consistency was reached; then the mixture and the water were mechanically mixed using a Hobart N50 apparatus at a speed of $126 \mathrm{rpm}$ for five minutes. For the compaction of the soil, the ASTM D1557-12e1 Method A was used [39]. Three samples were selected from each compacted formulation, obtained by hammering a 2" diameter aluminum tube, and a total of 21 soil samples. Using a hydraulic jack, soil samples were removed from the tubes. These samples were remolded and cut to 4 " height, and then, covered with plastic membrane in order to maintain the room temperature of $20 \pm 3{ }^{\circ} \mathrm{C}$ during an air-cured process for 28 days.

The sample fabrication and all tests were conducted at $20^{\circ} \mathrm{C}$, typical room temperature in Medellin. Viscosity of molasses decreases with temperature as shown below [40], from 
about 8 to 12 Pa.s ( 8000 to $12,000 \mathrm{cPs}$ ). Since molasses change with temperature, the current solution is for areas where the temperature variation is low, such as areas where people do not need AC or heater, like Caracas, Bogota, San Diego, Medellin, etc., [41]. In Medellin, for instance, the temperature variation is between 18 and $28^{\circ} \mathrm{C}$, which in the soil could be just $30 \%$ variation $\left(20\right.$ to $23^{\circ} \mathrm{C}$ ), a more acceptable temperature change. Future developments may consider thermal conductivity tests in order to increase insulation via materials science and thus decreasing even more the thermal changes.

For the characterization of the soil, specific gravity, liquid limit, optimum moisture content, plastic limit, and particle-size analysis, tests, have been performed according to respective ASTM test. The soil classification was done according to the ASTM D2487-17 by the Unified Soil Classification System (USCS) [42]. The density of soil samples was estimated based on weight and cylinder volume. Weight was measured using a Mettler Toledo balance, while the cylinder volume was measured using $0.05 \mathrm{~mm}$ precision caliper. Soil improvement was tested following the ASTM D2166-16 for the unconfined compression strength (UCS) [43]. For these tests, a universal testing apparatus Shimadzu AG250KN was used at a head speed of $0.68 \mathrm{~mm} / \mathrm{s}$.

$X$-ray diffraction (XRD) characterization was performed in a diffractometer $X^{\prime}$ Pert PRO, with $\lambda=1.5406 \AA, \mathrm{Cu} \mathrm{K} \alpha$ radiation, voltage of $45 \mathrm{kV}$, and angles between $5^{\circ}$ and $70^{\circ}$. Scanning electron microscopy with energy dispersive spectroscopy (SEM-EDS) was used to understand the microstructure of the samples in a JEOL JSM 6700 R equipment (Medellín, Colombia). For SEM, soil samples were dried at $30^{\circ} \mathrm{C}$ for $24 \mathrm{~h}$ in a furnace, and coated with gold in a sputtering system at $15 \mathrm{~mA} \mathrm{AC} \mathrm{for} 30 \mathrm{~s}$. Using the SEM images, the fiber diameter, rubber grain-size, and the mixed soil size distributions were estimated via image analysis with the Image-J software (version Java 1.8.0_172).

\section{Results}

\subsection{Materials Characterization}

The SEM-EDS results of the molasses shows this is mainly an organic compound, see Table 1, with oxygen and carbon with concentrations of $46.67 \%$ and $41.23 \%$ respectively. It also has potassium, calcium, and chlorine in concentrations of $6.86 \%, 2.1 \%$, and $2.08 \%$ respectively; and magnesium, and sulfur in lower concentrations of $0.64 \%$ and $0.41 \%$ respectively.

Table 2 summarizes the kaolin's index properties. According the USCS, the soil is a lean clay with sand (CL). Table 3 presents the experimental design for the formulations prepared. The fibers and molasses contents were estimated in a high precision balance. The soil was mixed with $35 \%$ of water, which is three percentage points up from the optimum moisture content to facilitate soil extraction without fracturing the samples (Table 2).

Table 2. Soil index properties.

\begin{tabular}{ll}
\hline Parameters & Values \\
\hline Soil classification & CL \\
USCS & \\
Atterberg limits & 44 \\
Liquid limit $(\%)$ & 23 \\
Plastic limit $(\%)$ & 21 \\
Plasticity index $(\%)$ & \\
Specific gravity & 2.75 \\
Specific gravity $\left(20^{\circ} \mathrm{C}\right)$ & \\
Particle-size distribution & 0.1 \\
Gravel $(\%)$ & 20.2 \\
Sand $(\%)$ & 40.5 \\
Silt $(\%)$ & 39.2 \\
Clay $(\%)$ & \\
Parameters of compaction & 1417 \\
Maximum dry density $\left(\mathrm{kg} / \mathrm{m}^{3}\right)$ & 32 \\
Optimum moisture content $(\%)$ &
\end{tabular}


Table 3. Soil mixtures.

\begin{tabular}{cccccc}
\hline Designation & Molasses(\%) & $\begin{array}{c}\text { Fibers } \\
\mathbf{( \% )}\end{array}$ & Soil(\%) & $\begin{array}{c}\text { Total \%(By } \\
\text { Dry Soil) }\end{array}$ & $\begin{array}{c}\text { \% Water } \\
\text { Content }\end{array}$ \\
\hline M0 & 0 & 0 & 100 & 100 & 35 \\
M2 & 2 & 0.1 & 97.9 & 100 & 35 \\
M4 & 4 & 0.1 & 95.9 & 100 & 35 \\
M6 & 6 & 0.1 & 93.9 & 100 & 35 \\
M8 & 8 & 0.1 & 91.9 & 100 & 35 \\
M10 & 10 & 0.1 & 89.9 & 100 & 35 \\
M12 & 12 & 0.1 & 87.9 & 100 & 35 \\
\hline
\end{tabular}

Figure 3a shows the particle-size distribution of the kaolin soil, with grain sizes from $0.2 \mu \mathrm{m}$ to $4.5 \mathrm{~mm}$, and the thickest particles corresponding to parental rock with less degree of weathering. Figure $3 \mathrm{~b}$ represents the polymer fibers diameter fitted in a normal probability distribution. Fibers showed a diameter from 10 to $40 \mu \mathrm{m}$, with an average of $22.4 \mu \mathrm{m}$. Figure $3 \mathrm{c}$ shows the rubber grain size in a normal probability distribution. These residual grains showed a diameter from 15 to $105 \mu \mathrm{m}$, with an average of $46.03 \mu \mathrm{m}$. When comparing these two size distributions for nylon diameters and rubber particles with the sieve analysis for the clay, it is clear that almost all particles are very fine, with very sharp distributions below $100 \mu \mathrm{m}$, suggesting a very particular mixture of materials in the microscale.
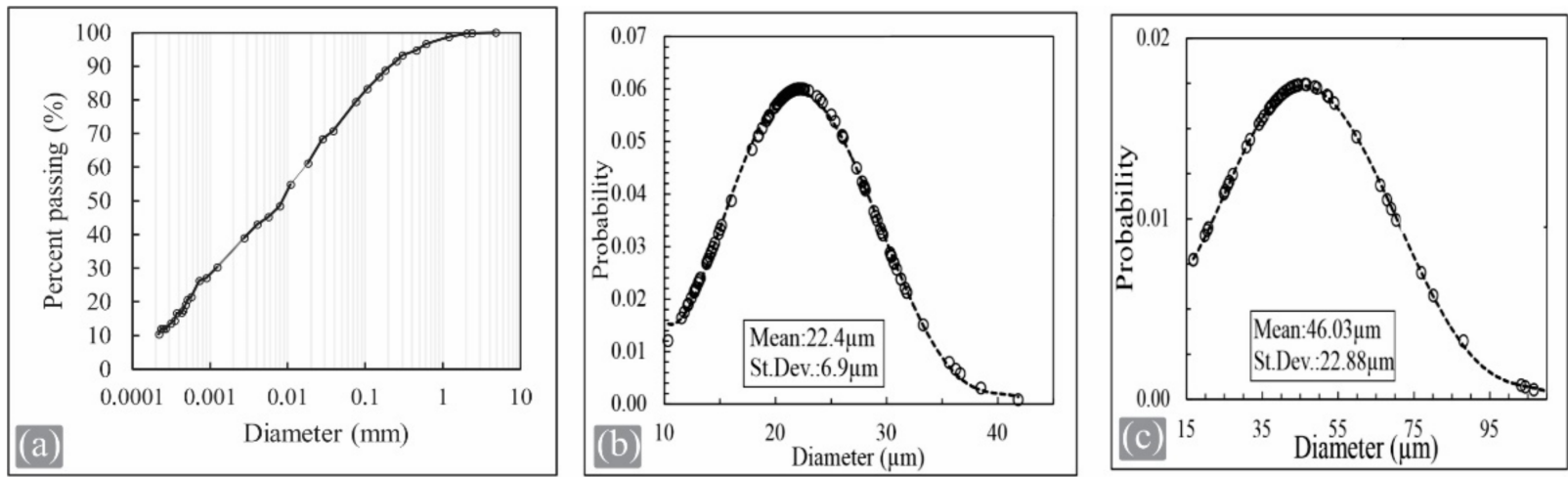

Figure 3. Grain/fiber diameter size distribution, (a) shows the particle-size distribution for the kaolin soil used, (b) shows the polymer fibers diameter distributions, (c) shows the residual rubber grain size distribution.

\subsection{Soil Mixtures}

Figure 4 shows the optical images representing the soil consistence and grain-sizes of the different mixtures used. These mixtures contain $0.1 \%$ fibers and $35 \%$ water by dry soil weight. As it can be seen, the molasses concentration has an important role in the grain-size formation, since as its concentration increases the grain-size of the mix becomes larger. Figure $4 \mathrm{a}-\mathrm{g}$ presents the different mixtures of soil with fibers, water, and molasses as summarized in Table 3.

Figure 5 shows the mixed soil grain-size probability distribution for each mixture prepared. The normal probability distribution represents the random nature of the grainsize forming process, and shows that as molasses content increases the statistical data dispersion and grain-size increase. Samples M0, M2, and M4 showed a distribution in a similar interval, see Figure 5a; while samples M6, M8, M10, and M12 were more diverse in the distribution values, see Figure $5 b$. 

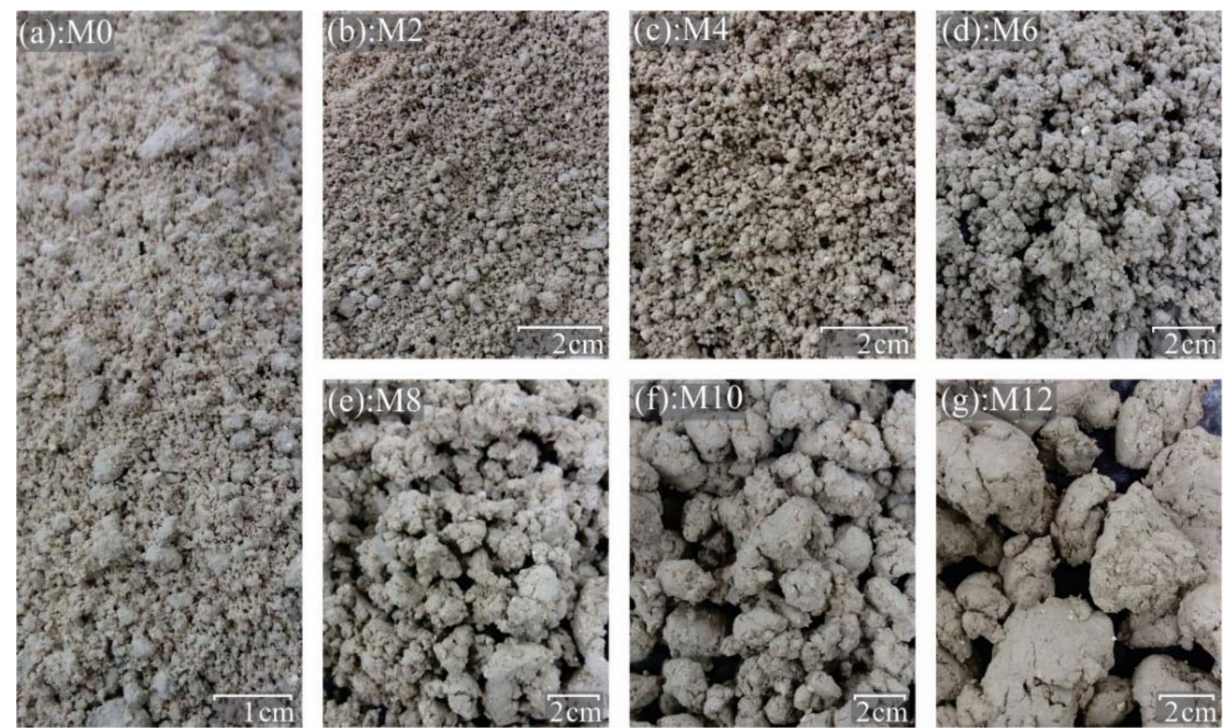

Figure 4. Optical images showing the soil consistence of mixtures.

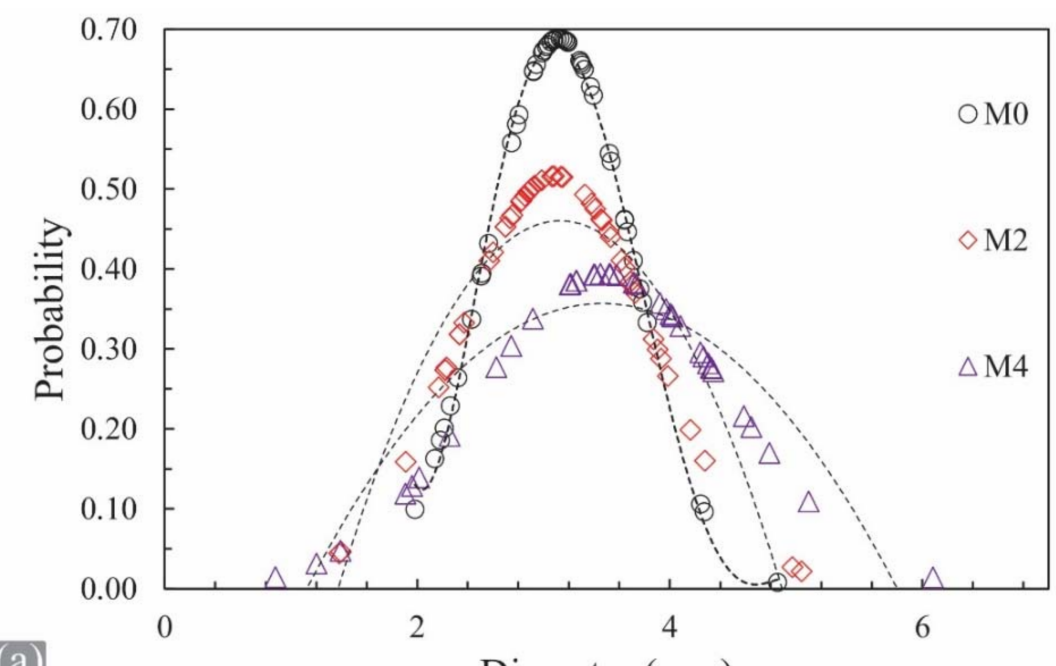

(a)

Diameter (mm)

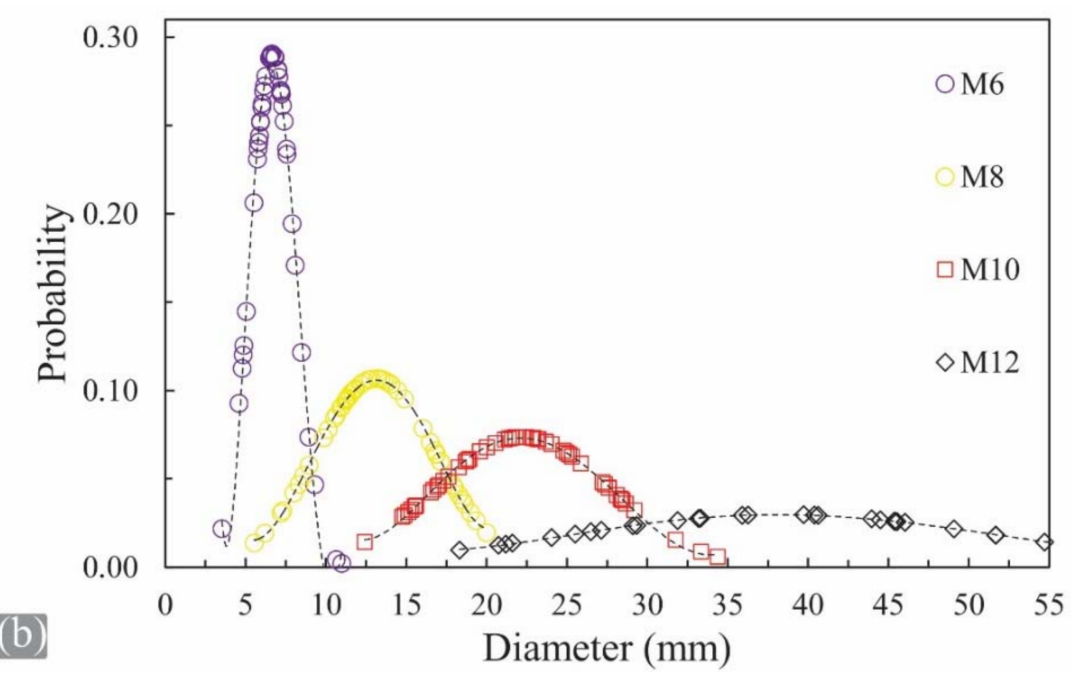

Figure 5. (a) Mixed soil grain size probability distribution for samples M0, M2, M4; (b) probability distribution for samples M6, M8, M10, M12. 
Figure 6 illustrates the XRD spectrum of soil. M0 red line corresponds to soil in its natural condition and the M12 blue line is the chemical composition of the soil after mixing the fibers, $35 \%$ of water and $12 \%$ of molasses by dry weight of soil. The MINCRYS database was consulted for mineral identification. Halloysite, kaolinite, illite, quartz, dickite, and goethite were identified as the crystalline phases constituting the clay. Kaolinite clay is the main plastic component of this soil, which is important as Colombia has plenty of kaolin-based soils. The particle size distribution via sieve method of the clay is presented before, were more than $80 \%$ of the soil is less than $0.1 \mathrm{~mm}(100 \mu \mathrm{m})$ in particle size.

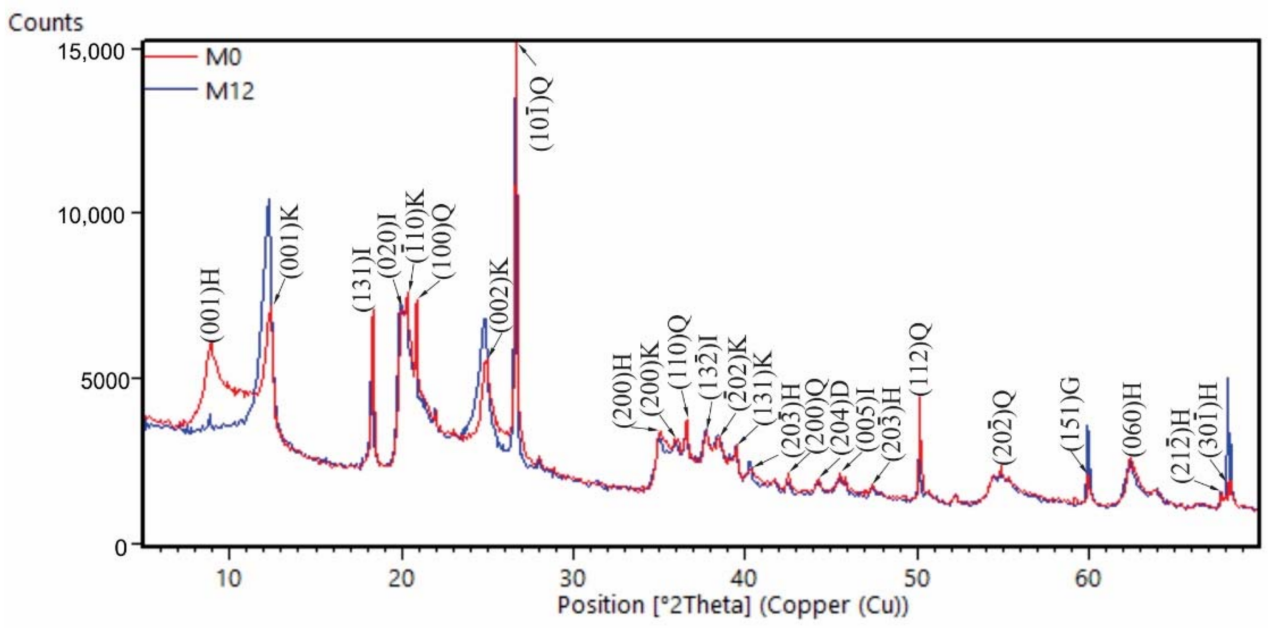

Figure 6. XRD spectrum for the soil. H: halloysite, K: kaolinite, I: illite, Q: quartz, D: dickite, G: goethite peaks.

\subsection{UCS Test}

Unconfined compression strength test (UCS) was performed using 21 samples, 3 in each batch. UCS and density results are given and compared in Figure 7. First, Figure 7a shows UCS result after 28 days of air curing. Second, Figure $7 \mathrm{~b}$ presents the UCS and ductility results against the molasses content. Finally, the sample density and the UCS/density ratio are also plotted against the molasses content in Figure 7c. UCS of soil in natural conditions (M0) was $1.34 \mathrm{MPa}$, for the mixture with optimum molasses content (M2) was 2.14 Mpa, and for the mixture with the maximum molasses content was 1.27 MPa.

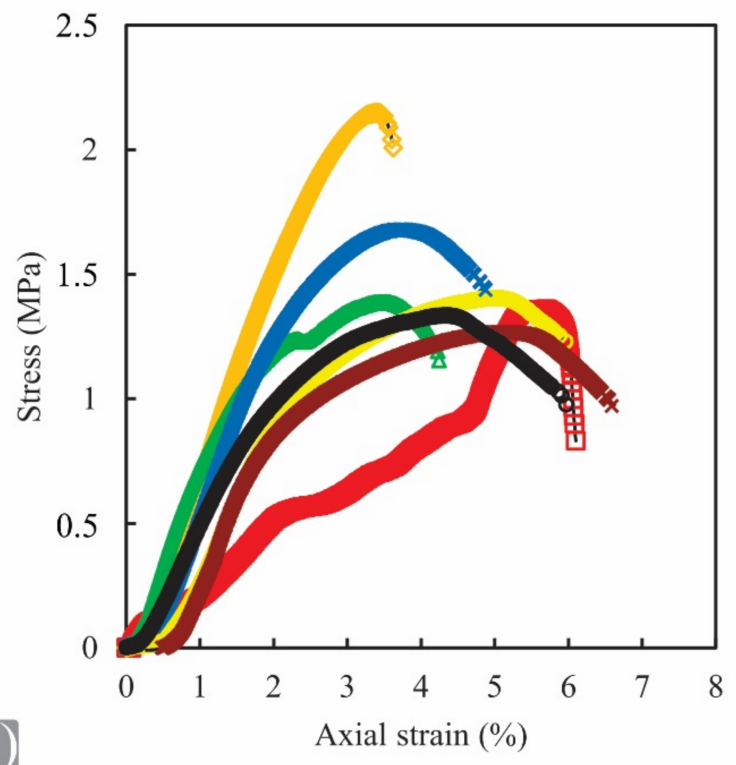

$$
\begin{aligned}
& \text { ๑-M0:0\% } \\
& \text { Molasses } \\
& -\diamond-\mathrm{M} 2: 2 \% \\
& \text { Molasses } \\
& \rightarrow \mathrm{M} 4: 4 \% \\
& \text { Molasses } \\
& \text { * M6:6\% } \\
& \text { Molasses } \\
& \text {--M8:8\% } \\
& \text { Molasses } \\
& \text { * M10:10\% } \\
& \text { Molasses } \\
& \text { - M12:12\% }
\end{aligned}
$$

Figure 7. Cont. 

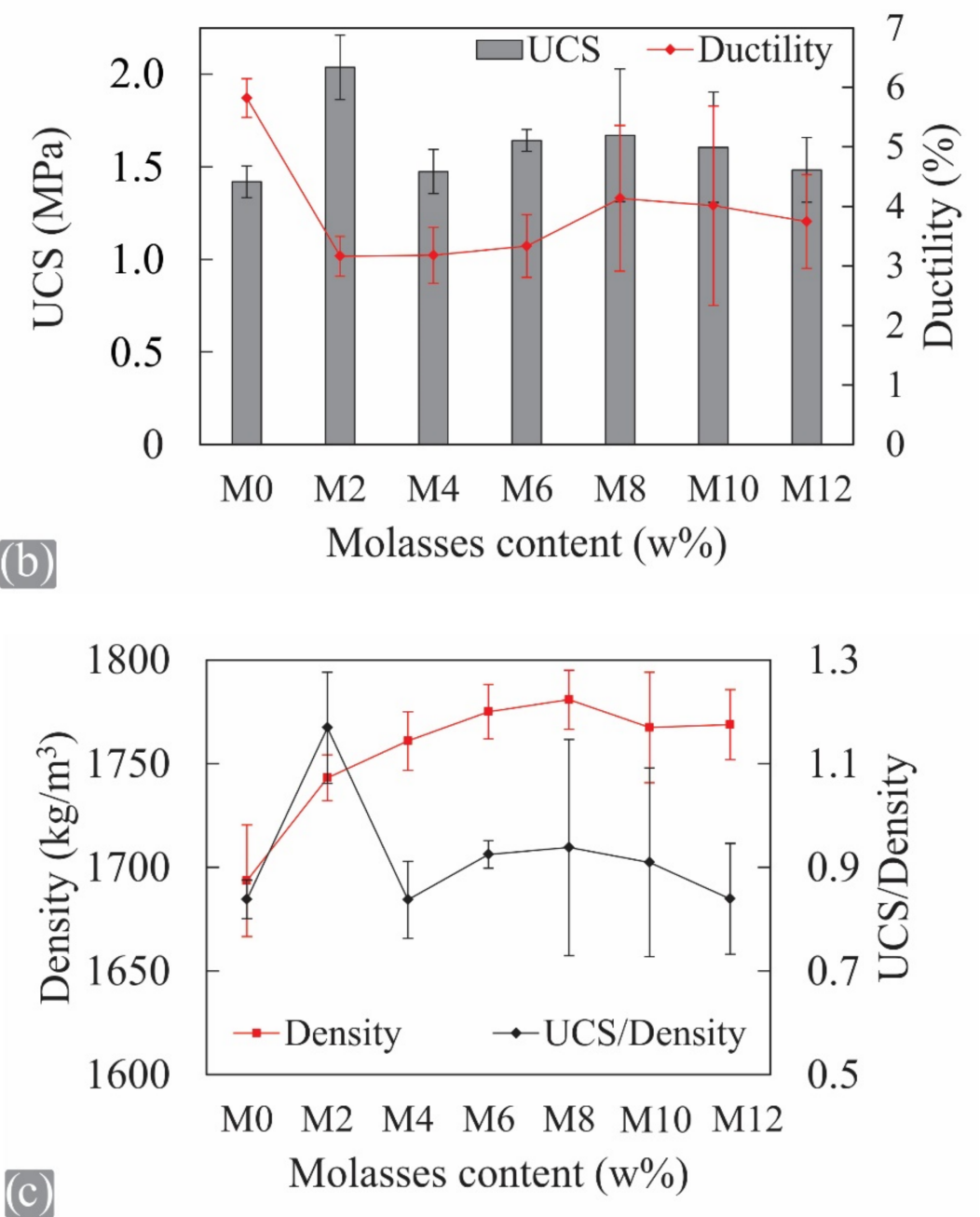

Figure 7. (a) UCS test, (b) UCS and ductility, (c) density and UCS/density.

Figure 8 presents the soil cylinders and failure characteristics of each mixture after compression tests, revealing different failure types, from a brittle failure in soil samples with low molasses content, to a more ductile failure in soils with higher molasses content. Therefore, molasses increases the possibility of a more ductile fracture and behavior.

\subsection{SEM Images Results}

Figure 9 shows SEM images results for some selected samples. Figure 10a shows the M2 soil sample taken at 500X, showing a fiber coming out from the soil matrix. Moreover, Figure $9 \mathrm{~b}, \mathrm{c}$ correspond to samples M2 and M4, with a fiber still attached to the soil and presenting a good impregnation of the soil to the fiber.

Figure 10 presents SEM-EDS images of kaolin soil. Figure 10a shows a $3 \times 10^{-3} \mathrm{~mm}^{2}$ spectrum SEM-EDS analysis of the structure and chemical composition of the soil used. Oxygen is the main element present in the material with a concentration of about $48.78 \%$; aluminum and silicon are also significant components with concentrations of about $23.46 \%$ and $24.66 \%$ respectively. Finally, the soil has low concentrations of thallium and iron, being $1.98 \%$ and $1.12 \%$ of the respective concentrations. Concentrations are given as percentage of weight. Figure 10b presents a $49 \mu^{2}$ spectrum SEM-EDS analysis of the soil showing bacterial growth in the soil under natural conditions. These are rod-like microorganisms with an average $0.5 \mu \mathrm{m}$ width and $15 \mu \mathrm{m}$ length and a concentration about $10^{4}$ microorganism $/ \mathrm{mm}^{2}$. 

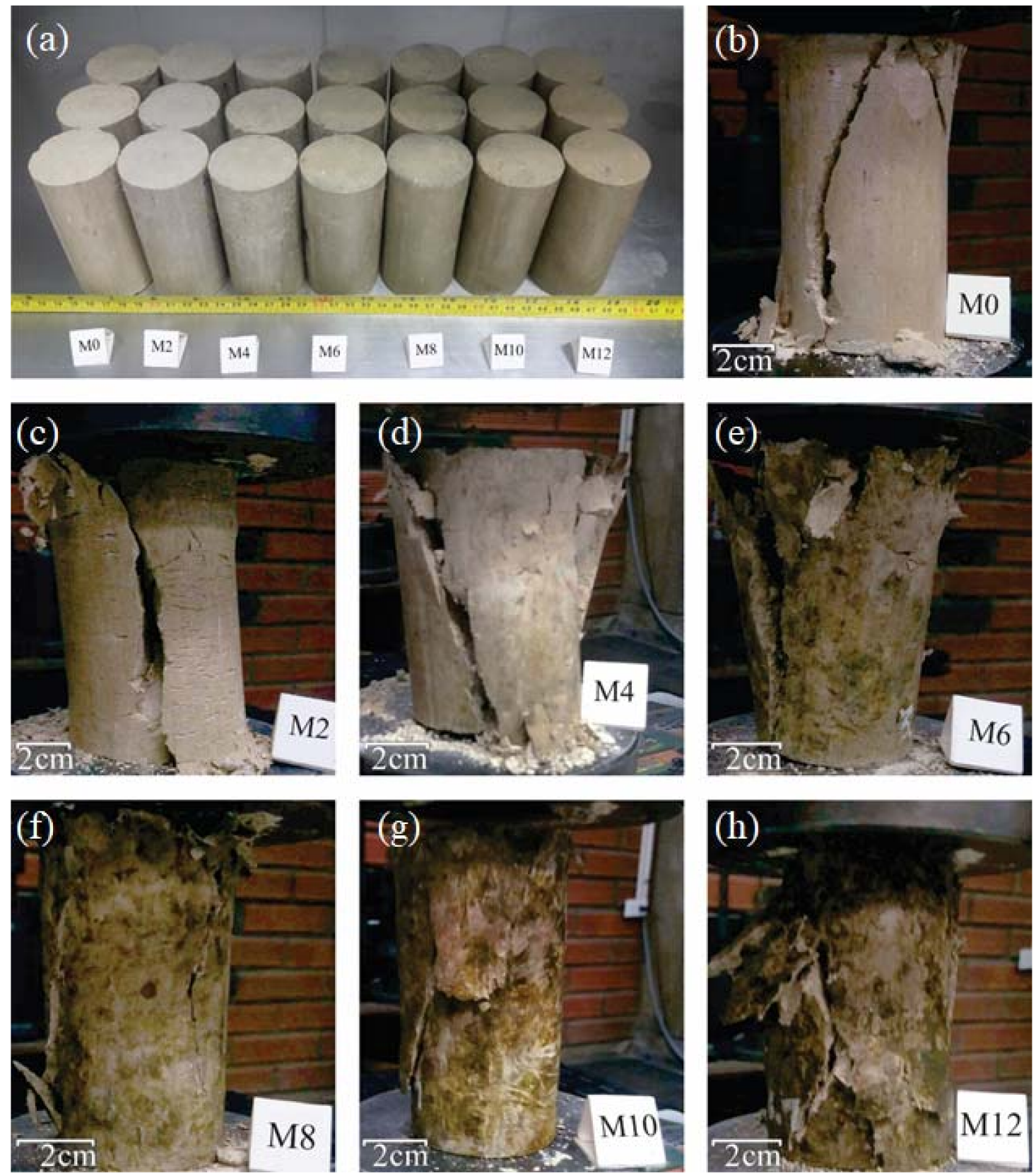

Figure 8. Soil samples after failure in compression tests: (a) samples before the test, (b) M0, (c) M2, (d) M4), (e) M6, (f) M8, (g) M10, (h) M12.
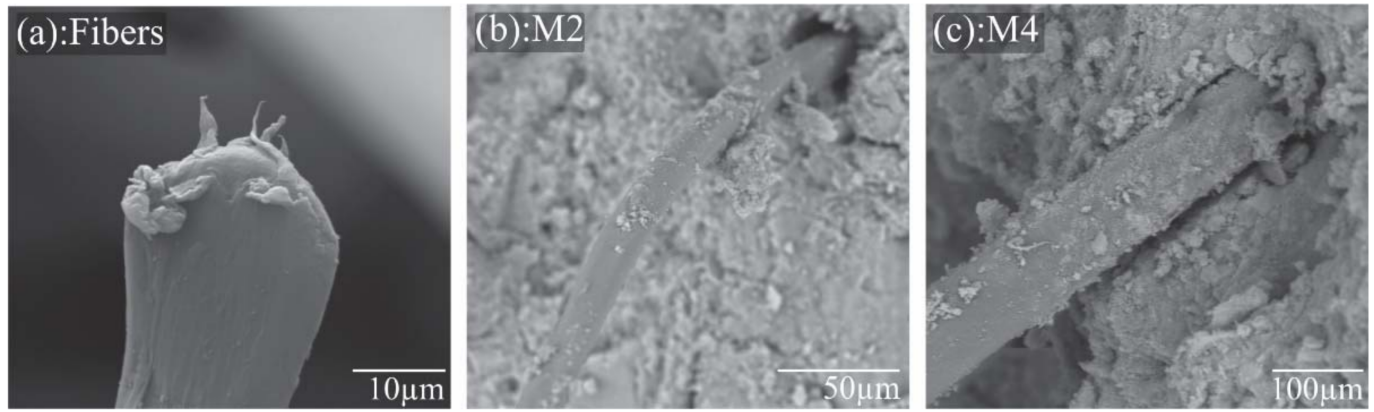

Figure 9. SEM images for (a) the end of a fiber; (b) the M2 soil sample, and (c) the M4 sample. 

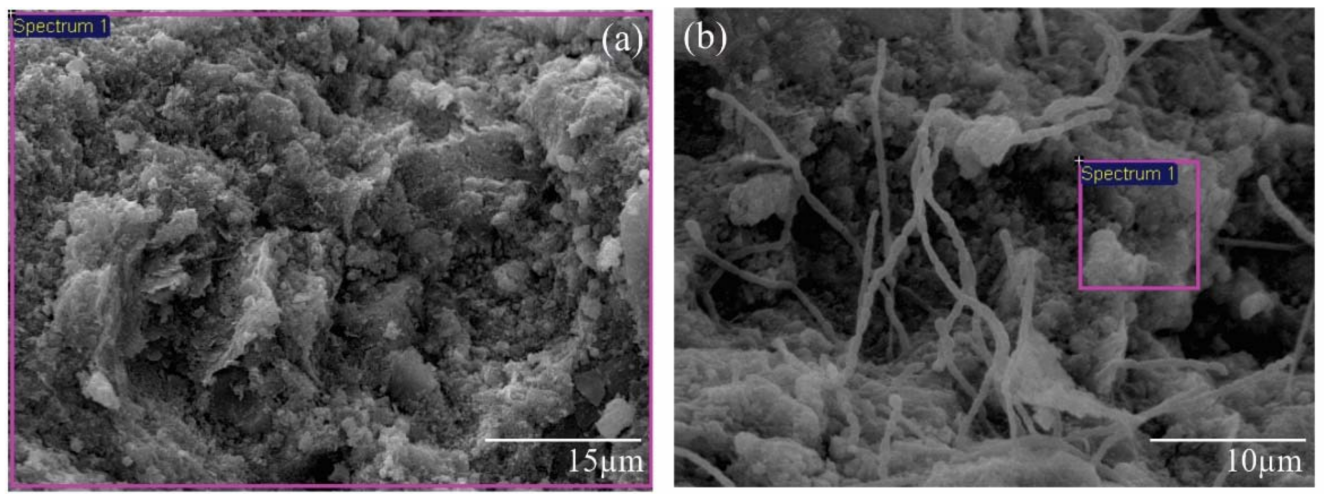

\begin{tabular}{|c|c|c|c|c|c|c|c|c|c|c|c|c|}
\hline Element & $\mathbf{O}$ & Al & $\mathrm{Si}$ & $\mathbf{T i}$ & $\mathrm{Fe}$ & Total & Element & $\mathbf{O}$ & Al & Si & $\mathbf{T i}$ & Total \\
\hline Weight (\%) & 48.78 & 23.46 & 24.66 & 1.98 & 1.12 & 100 & Weight (\%) & 47.17 & 24.71 & 27.17 & 0.95 & 100 \\
\hline Atomic (\%) & 62.76 & 17.9 & 18.08 & 0.85 & 0.41 & 100 & Atomic $(\%)$ & 60.77 & 18.88 & 19.94 & 0.41 & 100 \\
\hline
\end{tabular}

Figure 10. SEM-EDS for kaolin soil images, (a) soil used, (b) soil with bacterial growth.

Figure 11 shows the biological activity developed in sample M12. Figure 11a displays a microorganism that grew in the soil pores and extended around the micro-channels on the soil matrix with an average width of $2.6 \mu \mathrm{m}$, thickness of $0.4 \mu \mathrm{m}$, and thin film shape. Microorganism appeared after 4 days in some samples. In Figure 11b, another view of the microorganism described can be seen, as it rises from the bottom and has some particles adhering to it. Figure 11c shows the macro-scale image of microorganism growth in sample M12 at the external layer.
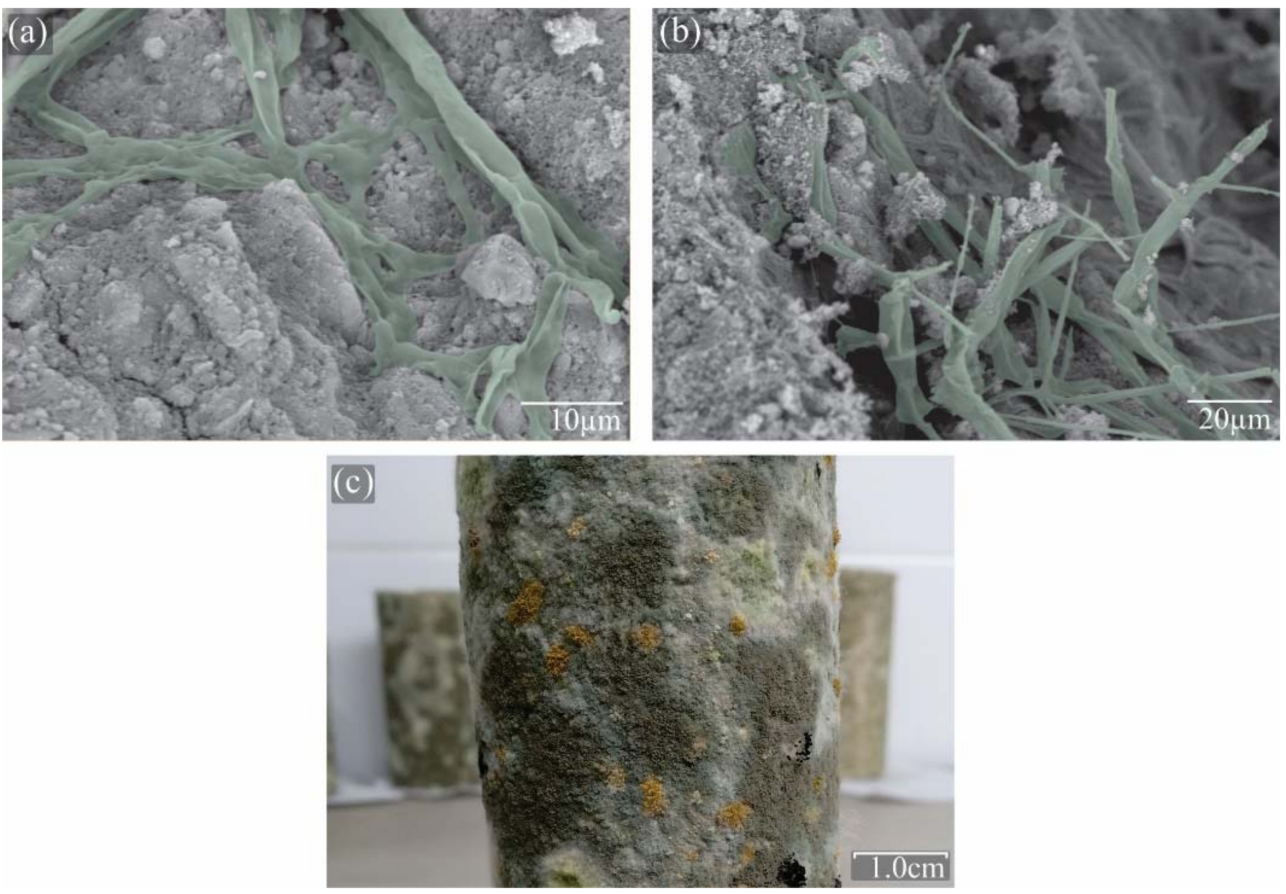

Figure 11. (a) Pseudo colored SEM images of M12 internal biological activity; (b) another area of the same sample showing a different configuration; (c) M12 external biological activity.

\section{Discussions}

Molasses have several potential uses in engineering applications due to aspects that give it advantages over conventional materials: it is soluble in water and without toxic components, an organic waste material derived from the food industry. Moreover, it is an inexpensive product, easy to acquire and with low dosages addition high maximum 
resistances can be achieved. For soil stabilization [44], If it is dosed at $2 \%$ by dry weight of soil, approximately $20 \mathrm{~kg}$ of molasses would be enough to process 1 ton of wet soil.

Saeed et al. [45] studied a kaolin with similar characteristics and engineering properties, treating it with different amounts of cement and curing times. The soil treated with $10 \%$ cement and cured for 28 days reached $2.10 \mathrm{MPa}$ in unconfined compressive strength test. Approximately $100 \mathrm{~kg}$ of cement were necessary to process 1 ton of wet soil. Despite the research undertaken by Saeed et al. [45] and this work are not strictly equal, they can be compared on the bases of material costs for ground stabilization. In Colombia, molasses costs an average $\$ 0.35 \mathrm{USD} / \mathrm{kg}$ and cement costs an average $\$ 0.17 \mathrm{USD} / \mathrm{kg}$. If 1 ton of soil is treated using cement, the costs would be approximately \$17 USD; while if the same amount of soil is treated using molasses the cost would be about \$7 USD. Although molasses is an inexpensive material when compared to cement, both as additives to soil, cement is a very competitive material when durability and strength are evaluated. Saeed et al. [45] concluded that $2 \%$ of molasses in dry soil matches the compression strength of soil with $10 \%$ cement, which is quite an impressive value. The durability on the other hand could be a limitation, as explained before, molasses changes very rapidly with time when compared with cement, although very little is known on this subject, therefore being a good area for research. Durability performance was not studied in this research, and it is possible that molasses does not provide the same durability as cement. However, soil improvement using molasses can be a temporal engineering solution.

Molasses are an organic material that suffers environmental degradation and aging. Therefore, the formulations properties of samples could be significantly affected. Research regarding the molasses stability in the soil have not been conducted yet, although future stability and chemical treatments for overcoming this issue are interesting as future research. Although biological activity was detected, a future systematic study will be conducted on the property's evolution and potential treatments as a function of the microorganisms' growth during the process. The samples were made under controlled fabrication procedure in this research, and the mechanical stability of the samples suggests that samples did not change significantly in a month, mainly because samples were made in a controlled environment, with constant atmosphere conditions. Regarding other construction applications under more severe conditions of temperature and load, the molasses have shown good stability [46] with load and temperature, but poor performance with moisture. Thus, to decrease the aging effect, for now, molasses has to be ideally at constant humidity. The clay used in this research in fact is a perfect material to keep the molasses isolated from water, to seal the soil as other clays [47], which is expected to decrease its natural and working-derived aging effects.

The Ministry of Transport in Colombia classifies tertiary roads as the routes that connect municipalities with rural municipalities [48]. Colombia has 142,284 km tertiary roads, of which $34,148 \mathrm{~km}$ do not have any engineering treatment [49]. Some of the aforementioned roads become impassable during the rainy seasons and thus soil improvement is required. Commonly, tertiary roads are stabilized using lime, cement, or a coarse aggregate structure. The analysis of behavior of the soils stabilized using molasses and its environmental impact is an environmentally friendly solution for ground improvement. This could reduce or replace the amount of cement used in tertiary roads, thus, reducing polluting gases generated by cement production. Clearly, this is not only a problem of Colombia, but also an issue in many developing countries.

There is a correlation in agglomerates between the liquid saturation and the growth rate of the agglomerates [50]. Interparticle forces are responsible for the formation of the agglomerates by attaching individual particles to each other [50]. The crushed soil in natural conditions mixed with water and $35 \%$ water content, has an average $3.12 \mathrm{~mm}$ diameter grain-size. Grain-size and its statistic data dispersion increase as molasses content increases. This occurs as the soil particles are agglomerated by the cohesion of molasses producing coalescence. The bonding forces necessary to obtain coalescence among agglomerates need to be significantly higher than the forces necessary for the primary particles' process of 
nucleation [51]. In this case, the high viscosity of the molasses increases the bonding forces between the soil particles facilitating coalescence between soil particles.

Addition of molasses has an important effect on the failure mode of the soil. As the molasses content increases the failure mode becomes more ductile. The base-line soil sample (M0) had a brittle failure in which shear cracks fell along a plane to the heading of compression. On the other hand, the soil with the highest content of molasses (M12) showed a plastic failure with multiple fractures extending from top to bottom. Soil samples with the highest UCS (M2 and M8) had a brittle failure with longitudinal splitting. When comparing the failure planes of the unstabilized sample (M0) and the samples with the highest UCS, the change in inclination indirectly shows a cohesion and an angle of internal friction rise.

\section{Biological Activity}

This research aims to investigate how molasses and fibers influence the unconfined compressive strength of soils. However, substantial biological activity was evidenced. SEM images showed the development of different microorganism in mixture M12 and after 7 days, microorganism grew on the external layer of the samples. To the naked eye, biological activity was not detected for the mixture with the optimum molasses content (M2). Intensity of the biological activity increases as molasses content increases, which can be used to improve the properties of soils, an area that falls in the bio-mediated soil improvement. This branch of geotechnical engineering has evolved to many methods, which includes bioclogging and biocementation. Bio-mediated methods for soil improving involves the generation of chemical reactions on soil mass that generate byproducts which change the engineering properties of the soil [52].

The use of microorganism to generate the reactions is an attractive and feasible alternative due to the number of microorganisms present in the soil and its resistance to extreme conditions. There are approximately $10^{9}$ to $10^{12} / \mathrm{Kg}$ of organisms of a soil mass near the ground surface [53]. For soil bioclogging or biocementation, the most recommended microorganisms are anaerobic and microaerophilic bacteria [54]. Biological activity is limited by nutrients availability, water availability, and other environmental conditions; carbon and mineral components as energy sources and pores larger than $0.4 \mu \mathrm{m}$ as environmental conditions are necessary to facilitate microorganism growth [55].

Biological activity was encouraged by conditions under which this research was performed. The molasses used had a composition of $41.2 \%$ carbon and $10.01 \%$ minerals like $\mathrm{Mg}, \mathrm{S}, \mathrm{K}, \mathrm{Ca}$. Due to its chemical composition, molasses is a considerable source of energy for microorganisms. On the other hand, water and $10-\mu \mathrm{m}$ pores in the soil stimulated growth of microorganism that are naturally found in the soil.

\section{Conclusions}

- The RTPF mixed with molasses represent a feasible, environmentally positive, economical, and technical alternative for ground improvement.

- Molasses are a byproduct of the repeated crystallization of sugar with no toxic elements and are environment-friendly. Due to its viscosity, molasses allows the separation of RTPF in soil, thereby producing a good composite solution.

- The improvement in the UCS achieved was of about $43 \%$, this is, from $1.42 \mathrm{MPa}$ for the reference sample, to $2.04 \mathrm{MPa}$ for the mixture sample, which contains $2 \%$ of molasses and $0.1 \%$ of RTPF.

Author Contributions: Conceptualization, H.A.C., C.M.F.V. and J.E.J.; methodology, H.A.C. and J.E.J.; validation, C.M.F.V.; investigation, J.E.J., C.M.F.V. and H.A.C.; writing-original draft preparation, H.A.C. and C.M.F.V.; writing-review and editing, H.A.C., J.E.J. and C.M.F.V.; supervision, H.A.C.; project administration, H.A.C. and J.E.J; funding acquisition, H.A.C. and J.E.J. All authors have read and agreed to the published version of the manuscript.

Funding: This investigation has not received external funding. 
Data Availability Statement: Datasets generated during the study can be found in: https:/ drive. google.com/drive/folders/1rjZUQ4tfEI0BoZUOd7LGEUw2A8BZQvmw? usp=sharing (accessed on 30 January 2022).

Acknowledgments: Authors would like to thank Juan Pablo Osorio from Universidad de Antioquia and Sumicol S.A. for supplying soil samples.

Conflicts of Interest: The authors declare no conflict of interest.

\section{References}

1. Sienkiewicz, M.; Kucinska-Lipka, J.; Janik, H.; Balas, A. Progress in used tyres management in the European Union: A review. Waste Manag. 2012, 32, 1742-1751. [CrossRef] [PubMed]

2. Rubber Manufactures Association. 2017 US Scrap tire Management Summary; Publisher Rubber Manufactures Association: Washington, DC, USA, 2019; pp. 1-20.

3. Ministry of Environment, Housing and Territorial Development. Available online: https://www.minambiente.gov.co/images/ AsuntosambientalesySectorialyUrbana/pdf/Programa_posconsumo_existente/RESOLUCION_1457_de_2010_1lantas.pdf (accessed on 10 February 2019).

4. District Secretary of the Environment. Available online: https:/ / ambientebogota.gov.co/c/document_library/get_file?uuid=2b1 cb194-bfd7-43d9-9350-11dd98b6f426groupId=10157 (accessed on 10 February 2019).

5. Observatorio Ambiental de Bogotá. Available online: https:/ / oab.ambientebogota.gov.co/es/indicadores?id=1057v=1\# (accessed on 10 February 2019).

6. Stevenson, K.; Stallwood, B.; Hart, A.G. Tire rubber recycling and bioremediation: A review. Bioremediat. J. 2008, 12, 1-11. [CrossRef]

7. Lebreton, B.; Tuma, A. A quantitative approach to assessing the profitability of car and truck tire remanufacturing. Int. J. Prod. Econ. 2006, 104, 639-652. [CrossRef]

8. Zebala, J.; Ciepka, P.; Reza, A.; Janczur, R. Influence of rubber compound and tread pattern of retreaded tyres on vehicle active safety. Forensic Sci. Int. 2007, 167, 173-180. [CrossRef] [PubMed]

9. Gieré, R.; Smith, K.; Blackford, M. Chemical composition of fuels and emissions from a coal+ tire combustion experiment in a power station. Fuel 2006, 85, 2278-2285. [CrossRef]

10. Zhang, X.; Wang, T.; Ma, L.; Chang, J. Vacuum pyrolysis of waste tires with basic additives. Waste Manag. 2008, 28, 2301-2310. [CrossRef]

11. Agudelo, G.; Cifuentes, S.; Colorado, H.A. Ground tire rubber and bitumen with wax and its application in a real highway. J. Clean. Prod. 2019, 228, 1048-1061. [CrossRef]

12. Shi, S.Q.; Wang, M.; Yin, P.; Luo, X. Experimental Study on a New Type of Waste Tires Combined Stone-blocking Structure. J. Disaster Prev. Mitig. Eng. 2011, 31, 501-505.

13. Yoon, Y.W.; Heo, S.B.; Kim, K.S. Geotechnical performance of waste tires for soil reinforcement from chamber tests. Geotext. Geomembr. 2008, 26, 100-107. [CrossRef]

14. Baricevic, A.; Pezer, M.; Rukavina, M.J.; Serdar, M.; Stirmer, N. Effect of polymer fibers recycled from waste tires on properties of wet-sprayed concrete. Constr. Build. Mater. 2018, 176, 135-144. [CrossRef]

15. Huang, B.; Li, G.; Pang, S.S.; Eggers, J. Investigation into waste tire rubber-filled concrete. J. Mater. Civil. Eng. 2004, 16, 187-194. [CrossRef]

16. Son, K.S.; Hajirasouliha, I.; Pilakoutas, K. Strength and deformability of waste tyre rubber-filled reinforced concrete columns. Constr. Build. Mater. 2011, 25, 218-226. [CrossRef]

17. Papakonstantinou, C.G.; Tobolski, M.J. Use of waste tire steel beads in Portland cement concrete. Cem. Concr. Res. 2006, 36, 1686-1691. [CrossRef]

18. Pilakoutas, K.; Neocleous, K.; Tlemat, H. Reuse of tyre steel fibres as concrete reinforcement. Proc. ICE-Eng. Sustain. 2004, 157, 131-138. [CrossRef]

19. Hataf, N.; Rahimi, M.M. Experimental investigation of bearing capacity of sand reinforced with randomly distributed tire shreds. Constr. Build. Mater. 2006, 20, 910-916. [CrossRef]

20. Revelo, F.C.; Colorado, H.A. A green composite material of calcium phosphate cement matrix with additions of car tire waste particles. Int. J. Appl. Ceram. Technol. 2021, 18, 182-191. [CrossRef]

21. Srivastava, A.; Pandey, S.; Rana, J. Use of shredded tyre waste in improving the geotechnical properties of expansive black cotton soil. Geomech. Geoengin. 2014, 9, 303-311. [CrossRef]

22. Zhao, J.; Wang, X.M.; Chang, J.M.; Yao, Y.; Cui, Q. Sound insulation property of wood-waste tire rubber composite. Compos. Sci. Technol. 2010, 70, 2033-2038. [CrossRef]

23. Rodriguez-Kabana, R.; King, P.S. Use of mixtures of urea and blackstrap molasses for control of root-knot nematodes in soil. Nematropica 1980, 10, 38-44.

24. Yunus, M.; Ohba, N.; Shimojo, M.; Furuse, M.; Masuda, Y. Effects of adding urea and molasses on Napiergrass silage quality. Asian-Australas. J. Anim. Sci. 2000, 13, 1542-1547. [CrossRef] 
25. Tiwari, S.P.; Singh, U.B.; Mehra, U.R. Urea molasses mineral blocks as a feed supplement: Effect on growth and nutrient utilization in buffalo calves. Anim. Feed. Sci. Technol. 1990, 29, 333-341. [CrossRef]

26. Aalm, A.; Singh, P. Experimental Study on Strength Characteristics of Cement Concrete by Adding Sugar Waste. Int. J. Enhanc. Res. Sci. Technol. Eng. 2016, 5, 33-34.

27. Zhang, Y.; Fei, A.; Li, D. Utilization of waste glycerin, industry lignin and cane molasses as grinding aids in blended cement. Constr. Build. Mater. 2016, 123, 785-791. [CrossRef]

28. M'Ndegwa, J.K. The effect of cane molasses on strength of expansive clay soil. J. Emerg. Trends Eng. Appl. Sci. 2011, 2, $1034-1041$.

29. Boopathy, R. Bioremediation of explosives contaminated soil. Int. Biodeterior. Biodegrad. 2000, 46, 29-36. [CrossRef]

30. Prasada, M.S.; Reid, K.J.; Murray, H.H. Kaolin: Processing, properties and application. Appl. Clay Sci. 1991, 6, 87-119. [CrossRef]

31. Ordoñez, E.; Gallego, J.M.; Colorado, H.A. 3D printing via the direct ink writing technique of ceramic pastes from typical formulations used in traditional ceramics industry. Appl. Clay Sci. 2019, 182, 105285. [CrossRef]

32. Revelo, C.F.; Colorado, H.A. 3D printing of kaolinite clay ceramics using the Direct Ink Writing (DIW) technique. Ceram. Int 2018, 44, 5673-5682. [CrossRef]

33. Shafiq, N.; Nuruddin, M.F.; Khan, S.U.; Ayub, T. Calcined kaolin as cement replacing material and its use in high strength concrete. Constr. Build. Mater. 2015, 81, 313-323. [CrossRef]

34. Heah, C.Y.; Kamarudin, H.; Al Bakri, A.M.; Bnhussain, M.; Luqman, M.; Nizar, I.K.; Liew, Y.M. Study on solids-to-liquid and alkaline activator ratios on kaolin-based geopolymers. Constr. Build. Mater. 2012, 35, 912-922. [CrossRef]

35. Babu, G.S.; Chouksey, S.K. Stress-strain response of plastic waste mixed soil. Waste Manag. 2011, 31, 481-488. [CrossRef] [PubMed]

36. Sivakumar Babu, G.L.; Chouksey, S.K. Analytical model for stress-strain response of plastic waste mixed soil. J. Hazard. Toxic Radioact. Waste 2011, 16, 219-228. [CrossRef]

37. García, F.E.; Pérez, A.C.; Colorado, H.A. Kaolinite-based clay ceramics blended with residual fique fibers for potential plastic soil applications. Int. J. Appl. Ceram. Technol. 2021, 18, 1086-1096. [CrossRef]

38. Sezer, A.; İnan, G.; Yllmaz, H.R.; Ramyar, K. Utilization of a very high lime fly ash for improvement of Izmir clay. Build. Environ. 2006, 41, 150-155. [CrossRef]

39. ASTM International (n.d). ASTM D1557-12e1 Standard Test Methods for Laboratory Compaction Characteristics of Soil Using Modified Effort (56,000 ft-lbf/ft3 (2700 kN-m/m3)). Available online: https:/ /www.astm.org/d1557-12r21.html (accessed on 10 February 2019).

40. Mišljenović, N.; Schüller, R.B.; Rukke, E.O.; Bringas, C.S. Rheological characterization of liquid raw materials for solid biofuel production. Annu. Trans. Nord. Rheol. Soc. 2013, 21, 61-68.

41. Cities of the World Where You Don't Need AC or Heat, Mapped. Available online: https://mnolangray.medium.com/cities-ofthe-world-where-you-dont-need-ac-or-heat-mapped-2a3d6e018970 (accessed on 10 January 2022).

42. ASTM International (n.d). ASTM D2487-17 Standard Practice for Classification of Soils for Engineering Purposes (Unified Soil Classification System). Available online: https://www.astm.org/d2487-17e01.html (accessed on 10 February 2019).

43. ASTM International (n.d). D2166M-16 Standard Test Method for Unconfined Compressive Strength of Cohesive Soil. Available online: https:/ / www.astm.org/d2166_d2166m-16.html (accessed on 10 February 2019).

44. Rahgozar, M.A.; Saberian, M.; Li, J. Soil stabilization with non-conventional eco-friendly agricultural waste materials: An experimental study. Transp. Geotech. 2018, 14, 52-60. [CrossRef]

45. Abdulhussein Saeed, K.; Anuar Kassim, K.; Nur, H. Physicochemical characterization of cement treated kaolin clay. Građevinar 2014, 66, 513-521.

46. Hareru, W.; Ghebrab, T. Rheological Properties and Application of Molasses Modified Bitumen in Hot Mix Asphalt (HMA). Appl. Sci. 2020, 10, 1931. [CrossRef]

47. Alther, G.R. The qualifications of bentonite as a soil sealant. Eng. Geol. 1987, 23, 177-191. [CrossRef]

48. Ministerio de Transporte. Manual de Diseño Geométricos de Carreteas; Instituto Nacional de Vías: Bogotá, Colombia, 2008.

49. Departamento Nacional de Planeación. Available online: https://colaboracion.dnp.gov.co/CDT/Prensa/Presentaciones/RED\% 20TERCIARIA\%20CCI\%20-\%20DNP.pdf (accessed on 27 May 2019).

50. Kristensen, H.G. Particle agglomeration in high shear mixers. Powder Technol. 1996, 88, 197-202. [CrossRef]

51. Lian, G.; Thornton, C.; Adams, M.J. Discrete particle simulation of agglomerate impact coalescence. Chem. Eng. Sci. 1998, 53, 3381-3391. [CrossRef]

52. DeJong, J.T.; Mortensen, B.M.; Martinez, B.C.; Nelson, D.C. Bio-mediated soil improvement. Ecol. Eng. 2010, 36, 197-210. [CrossRef]

53. Umar, M.; Kassim, K.A.; Chiet, K.T.P. Biological process of soil improvement in civil engineering: A review. J. Rock Mech. Geotech Eng. 2016, 8, 767-774. [CrossRef]

54. Ivanov, V.; Chu, J. Applications of microorganisms to geotechnical engineering for bioclogging and biocementation of soil in situ. Rev. Environ. Sci. Bio/Technol. 2008, 7, 139-153. [CrossRef]

55. Mitchell, J.K.; Santamarina, J.C. Biological considerations in geotechnical engineering. J. Geotech. Geoenviron. Eng. 2005, 131, 1222-1233. [CrossRef] 